quence, unable to obtain its position except by estimation.

At twenty minutes past seven I estimated it to have been in about R. A. 22 h. 57 m., Dec. + $29^{\circ}$ $50^{\prime}$, as determined by comparison with Argelander's charts, no allowance for precession being made. It was $2^{\circ} 37^{\prime}$ almost exactly north of Beta Pegasi, as roughly determined by the size of the field of my comet eye-piece. Its motion is slowly eastward, probably north-east; but its altitude was so low, and the hour being so near moonrise, I could not determine its exact direction.

It presented a beautiful appearance through my $4 \pi / 2$-inch achromatic.

Warner observatory, Rochester, Feb. 24.

\section{Movement of the arms in walking.}

In Scinnce, Feb. 9, Mr. F. W. True recognizes the 'movement of the arms in walking' as a functional relic of quadrupedal locomotion; urging thereby a modification of the expression of Professor Dana, sanctioned by Dr. Gill, that "man stands alone among mammals in having the fore-limbs not only prehensile, but out of the inferior series, the posterior pair being the sole locomotive organs." And the questions are asked, "Have we not at least a ghost of a preexisting function? Does man walk by means of his feet and legs alone?', Viewing the question from the developmental standpoint, it seems to me that the strongest evidence appears in the first locomotor-acts of the child. Before bipedal progression is learned, the child goes on all-fours, and is an actual mammalian quadruped. At the beginning of this the prehensile power of the fingers is very imperfect. Men have been known to educate their toes to do more than the fingers can at that stage of functional development. At that time the palms are of more value as soles than for holding things. In the beginning, also, the arms in some children are better legs than are the hind-limbs, being more easily used. For example, it is more common for children to creep on the knees than on the elbows; but some learn remarkably early to elevate both knees and elbows, to creep on the soles and palms. My own boy walked on his soles and palms from the start, and never upon his knees. The speed with which he finally learned to run in this way was remarkable. After learning to move somewhat on his hind-legs, when he got in such haste as to make bipedal balancement difficult or uncertain, he would take to all-fours, thereby making better speed with less danger of a fall.

U.S. dept. of agric., Washington, Feb. 13, 1883 .

W. S. BARNARD.

\section{The heart as a locomotive organ.}

Every one has observed that the tendency of the heart to beat while walking 'is a most natural one.' 'The action is rhythmical,' the number and force of the pulsations varying with the velocity of the walk. 'It is also involuntary;' but, although proper locomotive movements are usually in a high degree voluntary, this consideration need cause us no uneasiness, if we reflect, that, when its action is from any cause suspended, 'an air of stiffness' is soon imparted to the whole body.

In view of these facts, does it not seem that the statement (SCIENCE, p. 11) that " man stands alone among mammals in having the fore-limbs not only prehensile, but out of the inferior series, the posterior pair being the sole locomotive organs," should be further modified, and the heart assigned its proper place between the swinging arms as a true locomotive organ?

New Haven, Feb. 28.

\section{The copper-bearing rocks of Lake Superior}

There are one or two statements in Mr. Selwyn's remarks on the age of the rocks on the northern shore of Lake Superior, in the number of your journal for Feb. 9, which I cannot suffer to pass unchallenged.

I cannot enter here into a general discussion of the much-vexed question of the age of the Lake Superior copper rocks, - I have discussed it at length elsewhere, ${ }^{1}$ - but I must take issue with the statement that there is " no evidence whatever of their holding any other place in the geological series" than that which "includes the Potsdam and Primordial Silurian." My own conclusions in this connection, after an examination of most of the circuit of Lake Superior, are: -

$1^{\circ}$. That the copper-bearing rocks underlie unconformably - and with an immense unconformity-a series of sandstones holding Cambrian fossils. These fossils may not correspond to the oldest Cambrian fossils known elsewhere, as argued by N. H. Winchell in the report quoted, but they are distinctly Cambrian; and if the copper-bearing strata are to be called Cambrian, then we must stretch that term over a most immense unconformity, in order to include a rock-series holding no fossil evidence of its Cambrian age, - a thing which appears to me very unreasonable to do. This unconformity is best seen in the St. Croix river region of western Wisconsin, and thence north-eastward. Although attention was drawn some years since by Sweet, Chamberlin, and myself, ${ }^{2}$ to the strikingly conclusive occurrences of this region, our evidence has been ignored by others who have never examined the region, and who continue to approach the question from the eastward, or, in other words, from the same direction as a succession of geologists, from Houghton to Selwyn, all of whom have felt baffled. It is interesting to note in this connection that $\mathrm{N}$. H. Winchell, the only geologist who has gone to the St. Croix since our report was issued, confesses to the unconformity, ${ }^{3}$ although he had strenuously refused to believe in it before visiting the region. It does not seem to me that any geologist can honestly deny this unconformity until he has done as we have done; viz., followed the copper-bearing strata, with all their characters preserved, mile by mile, from the typical region of Keweenaw Point, to their junction with the fossiliferous Cambrian sandstone of the St. Croix valley.

$2^{\circ}$. That the copper-bearing strata also underlie unconformably the 'eastern sandstone' of the south shore of the eastern half of Lake Superior. Winchell has argued a difference of age between this sandstone and that of the St. Croix valley. However this may be,and I have myself seen no evidence that the one of these sandstones is not merely the direct downward continuation of the other, - the work done by myself and assistants along the contact line of the copperbearing rocks, and the eastern sandstone from Bête Grise Bay westward to the vicinity of Lake Agogebic, has served to convince me that there is here also an unconformity as great as the other.

$3^{\circ}$. That the time-gap between the copper-bearing series and the Huronian was too long to allow of our classing them together, - for it certainly covered a considerable amount of denudation and alteration, but it is still doubtful if this gap was long enough to cover the folding of the folded Huronian. The greatest confusion prevails as to the use of the term $\mathrm{Hu}$ -

1 The copper-bearing rocks of Lake Superior, - vol. v., monographic publications of the U.S. geol. survey; also Third annual report of the same survey. Both of these publications are still under press.

2 Geology of Wisconsin, vol. iii. $\quad 3$ Loc. cit., p. 134. 